Kodifikasia : Jurnal Penelitian Islam, Vol 14, No. 02 (2020), 325-338

DOI : 10.21154/kodifikasia.v14i2.2223

ISSN : 1907-6371 (Cetak)

ISSN : 2527-9254 (Online)

\title{
THE CHANGE IN THE HAGIA SOPHIA MUSEUM BY ERDOGAN: HISTORICAL PERSPECTIVE AND ITS IMPLICATIONS FOR INDONESIAN
}

\author{
Budi Sujati, * Wahyu Iryana**
}

\begin{abstract}
Abstrak
Peristiwa Penaklukan Konstantinopel pada 1453 menjadi sorotan dunia sekarang ini salah satu pemicunya adalah presiden Turki Recep Tayyip Erdogan mengubah kebijakan status museum Hagia Sophia menjadi Masjid. Hal tersebut mendapatkan respon yang luar biasa dari masyarakat dunia terutama dari Barat dan Islam. Pro dan kontra muncul karena mereka menilai status Hagia Sophia merupakan warisan dunia yang tidak boleh berganti statusnya dan harus menjadi benda cagar budaya. Dari kubu yang mendukung memiliki argumentasi bahwa merupakan hak dan kebebasan suatu negara untuk merubah identitasnya dengan dukungan rakyatnya. Sementara mereka yang menolak status perubahan tersebut dikarenakan akses untuk mengunjungi tempat paling suci dan sakral akan mengalami kesulitan sehingga akan sulit untuk mengunjunginy a dengan bebas. Penelitian ini bersifat deskriptif dengan metodologi kualitatif. Metodologi ini digunakan agar bisa menjelaskan suatu fenomena yang terjadi sekarang mengenai isu Hagia Sophia. Salah satu fenomena yang muncul di Indonesia, isu ini mendapat sorotan media nasional hingga internasional bahkan sampai viral. Sebagai umat Islam langkah yang diambil dalam mengambil keputusan yang bijak sesuai dengan sejarahnya melalui pendekatan sejarah dengan tahap heuristik, kritik, interpretasi, dan historiografi.
\end{abstract}

Kata Kunci: Hagia Sophia; Masjid; Museum,

* Sekolah Tinggi Keguruan dan Ilmu Pendidikan Pangeran Dharma Kusuma Indramayu, email : budisujati@gmail.com.

** Sekolah Tinggi Keguruan dan Ilmu Pendidikan Pangeran Dharma Kusuma Indramayu,email : wahyuiryana@yahoo.com. 


\begin{abstract}
The Conquest of Constantinople in 1453 is in the spotlight of the world today. One of the triggers is the Turkish president Recep Tayyip Erdogan changing the policy of the status of the Hagia Sophia museum into a mosque. This has received a tremendous response from the world community, especially from the West and Islam. Pros and cons arise because they consider the status of the Hagia Sophia to be a world heritage that cannot change its status and must become a cultural heritage object. Those from the supporting camp have argued that it is the right and freedom of a country to change its identity with the support of its people. Meanwhile, those who refuse the change of the status due to access to the most holy and sacred places will experience difficulties so that it will be difficult to visit them freely. This research is descriptive with a qualitative methodology. This methodology is used to explain a current phenomenon regarding the issue of the Hagia Sophia. One of the phenomena that have emerged in Indonesia, this issue became a prime focus of the national to the international media and even viral. As Muslims, steps are taken in making wise decisions by their history through a historical approach with the step of heuristic, criticism, interpretation, and historiography.
\end{abstract}

Keywords: Hagia Sophia; Museum; Mosque.

\title{
INTRODUCTION
}

Recently President Recep Tayyip Erdogan made a decision that make the world shocked, especially for Muslims and Christians. How not, the historical building monument, Hagia Sophia, which was originally a museum since 1934 has been converted into a mosque. Then this policy raises the pros and cons of Muslims and Christians in the world. ${ }^{1}$ In Siti Rohmah Soekarba's research who asked whether the Hagia Sophia was a symbol of European Christianity or Turkish Islam. ${ }^{2}$ Here, if we see, according to Soekarba, Christians and Muslims have each other's rights. Among them, Christianity was the first to build the Hagia Sophia, and Islam which continued and cared for one of the world's cultural heritage. During its development, when there was an issue of changing a museum that could

${ }^{1}$ Justin Ott, The Decline and Fall of The Western Roman Empire (Iowa: Iowa State University, 2009), 1.

2 Siti Rohmah Soekarba, "Makna, Ruang dan Tempat, Pada Hagia Sophia, Istambul Turki," Middle East and Islamic Studies Journal 7(1) (2020): 113.

Kodifikasia: Jurnal Penelitian Islam, Volume, 14 No. 2 Tahun 2020 
be accessed by all mankind, it was turned into a mosque which received an extraordinary response. ${ }^{3}$

One of the responses that came was from Western countries, including the United States, which said they were very disappointed with Turkey's decision to change the legacy of the Eastern Roman Empire (Constantinople) which was converted from a museum to a mosque and urged immediately access to world cultural heritage. ${ }^{4}$ One of Turkey's neighbors also said the same thing, namely Greece. Greek Prime Minister Kyriakos Mitsotakis said in a statement that Greece condemned Turkey's decision to turn the Hagia Sophia Museum into a mosque, an option that offends everyone who recognizes the monument as a world heritage site. The implications of this Turkish policy affect not only Turkey's relations with Greece but also its relations with the European Union. ${ }^{5}$

Not only from Western countries that are against it, but there are also Muslims who support Turkey's policy, one of them is the Palestinian Hamas group. According to Rafat Mura, head of the International Hamas office, through a written statement from the Anadolu Agency website on Saturday, July 11,2020 , saying that making the Hagia Sophia a place of prayer is a proud moment for the world's Muslims. He supports and welcomes Turkey's decision to turn the Hagia Sophia Museum into a mosque. The change in status took place after the Turkish court annulled the status of the Hagia Sophia as a Museum which had been established by the founding father of modern Turkey Mustafa Kemal Pasha in 1934. ${ }^{6}$ Meanwhile in Indonesia itself through Fadli Zon (chairman of the Inter-Parliamentary Cooperation Agency of the House of Representatives of the Republic of Indonesia) so that all parties respect each other especially respecting Turkey's sovereignty. The Modern Republic of Turkey, however, relies on its identity on the Ottoman Turks, while the East Rome (Constantinople), which historically and culturally has now become a Greek state. ${ }^{?}$

\footnotetext{
${ }^{3}$ Deutche Welle, "Uni Eropa Kecam Turki atas Berubahnya Status Hagia Sophia," republika.co.id, 2020, https://republika.co.id/berita/uni-eropa-kecam-turki-atasberubahnya-status-hagia-sophia.

${ }^{4}$ Ahmad Naufal Dzulfaroh, "Beragam Respons Dunia atas Perubahan Status Hagia Sophia Menjadi Masjid,” kompas.com, 2020, https:/www.kompas.com/tren/beragamrespons-dunia-atas-perubahan-status-hagia-sophia-menjadi-masjid.

${ }^{5}$ Rizky Jaramaya dan Muhammad Hafil, "Yunani Kecam Turki Ubah Hagia Sophia Menjadi Masjid,” republika.co.id2, 2020, https://republika.co.id/berita/yunani-kecamturki-ubah-hagia-sophia-menjadi-masjid.com.

${ }^{6}$ Sri Mulyati, "Transformasi Budaya dari Khilafah Turki Utsmani Menuju Republik Turki Modern (1830-1950)," CMES (Center of Middle Eastern Studies) 7(1) (2014): 9.

7 Muhammad Subarkah, "Hagia Sofia Menjadi Masjid: Bagaimana Sikap Indonesia?," republika.co.id, 2020, https://republika.co.id/berita/hagia-sofia-menjadi-masjidbagaimana-sikap-indonesia.
} 
Based on the above problems, the issue of the Hagia Sophia as a Museum or Mosque has become a hot topic of discussion in the world, especially by groups promoting the return of the concept of the caliphate in the Islamic world, including in Indonesia. The Caliphate as an idea sounds radical and has a negative connotation. Even though there is a fact that the Caliphate has existed in most of the periods of Muslim history, especially the heyday of the Ottoman Turks. There are many positive things about the presence of the Caliphate for the Muslim World. It's just that, the caliphate narratives that emerged later seemed to force the return of the Caliphate regardless of the context of the era by means of an unconstitutional way. The millennial generation itselves needs balanced information about the caliphate in the Islamic world from a historical approach.

This This article is very important to write, because the issue of Hagia Sophia, whose status changed to a mosque, received a tremendous response, including in Indonesia. In Indonesia, the issue of Hagia Sophia has become the legitimacy of Islamic fundamentalist groups to mobilize Muslims against the legitimate government, namely President Joko Widodo, which they say criminalizes cleric. This article is expected to contribute historical knowledge regarding the Ottoman Caliphate if you look at the current context by looking at the journey of Sultan Muhammad Al-Fatih in conquering Constantinople in 1453 by seeing the phenomenon in Indonesia today. With this knowledge, a better understanding of the Caliphate will be built for Muslims in the world and especially Muslims in Indonesia. ${ }^{8}$

History as a discipline tries to see things from the point of view of time span. It means seeing change, continuity, backwardness, and leaps. Apart from that, history has other jobs, he is interested in discussing the origin of the seedlings, when the tree grows, when it branches and twigs, what is the state of the branches and twigs, what is the reason for one branch to flourish. ${ }^{9}$ In connection with the currently popular issue regarding the change in the status of the Hagia Sophia Museum to the Hagia Sophia Mosque, a historical approach is needed to dissect it.

The approach is aligned with a certain science, the approach is a way of approaching objects so that history as information can be revealed clearly and becomes a lesson for mankind so that bad events do not occur for future generations and good events can become role models for the present generation. ${ }^{10}$ In this study, the scope to be studied is that the conquest of

${ }^{8}$ Dewi Ratnasari, "Sulaiman Al-Qanuni: Sultan Terbesar Kerajaan Turki Utsmani," Thaqafiyyat 14(1) (2013): 74.

9 Kuntowijoyo, Metodologi Sejarah, 2 ed. (Yogyakarta: Tiara Wacana, 2003), 159.

${ }^{10}$ Nyoman Kutha Ratna, Metodologi Penelitian kajian Budaya dan Ilmu Sosial Humaniora pada umumnya (Yogyakarta: Ombak, 2020), 59.

Kodifikasia: Jurnal Penelitian Islam, Volume, 14 No. 2 Tahun 2020 
Constantinople by the Ottoman Turks had an impact on Muslims, especially when Turkish President Recep Tayyip Erdogan carried out a policy that was considered phenomenal and crucial in changing the Hagia Sophia Museum into the Hagia Sophia Mosque which raised pros and cons, especially from Western countries by looking at hardline Islamic activists in Indonesia. The hope is that with this article readers can see and know how the context of the conquest of Constantinople is seen from a historical point of view so that we can fully understand how our attitude as wise humans is to see the pros and cons of changing the Hagia Sophia Museum into the Hagia Sophia Mosque.

\section{DISCUSSION}

\section{Background of the Constantinople's Conquest}

Muhammad Al-Fatih received power from his father Sultan Murad II at the age of 22. The first thing he did was to send Mara Brankovic the wife of his late Serbian father to his parents, then kill his half-sister Ahmad, who was still breastfeeding. ${ }^{11}$ Before conquering Constantinople by Muhammad Al-Fatih who later changed his name to Istanbul which became the capital of the Ottoman Turks, the capital of the Ottoman Empire was Adrianople (Edirne) which was conquered by Sultan Murad I in 1366, a strong foothold in mainland Europe. ${ }^{12}$ The transfer of the capital was carried out in order to make it easier for the Ottoman Turks to move in Europe. The city of Edirne remained the capital of the Ottoman Turks until it was able to conquer Constantinople (Capital of the East). ${ }^{13}$

Prior to conquering Constantinople because of their characteristic spirit of expansion beyond the Turks, a number of these Ottoman conquests into Europe sought to emulate a vast Ancient European country. In order to contain the expansion of the Ottoman Turks, European countries tried to mobilize a number of troops which were later known as Crusaders. In 1396 a re-coalition organized by the Pope and from Venice Italy was defeated in the Battle of Nicopolis. ${ }^{14}$ In 1444, the Pope along with several coalitions with several powers including the kings of Hungary, Poland, Naples, and

${ }^{11}$ Tim Riset dan Studi Islam Mesir, Ensiklopedi Sejarah Islam; Imperium Muslim Mongol, Negara Usmani, Muslim Asia Tenggara, Muslim Afrika (Jakarta: Pustaka al-Kautsar, 2014), 168.

${ }^{12}$ Philip K Hitti, History of the Arabs; From the Earlist Times to the Present (New York: Palgrave Macmillan, 2000), 905.

${ }^{13}$ Gulru Necipoglu, Hagia Sophia from The Age of Justinian to The Present (Cambridge: Cambridge University Press, 199M), 204.

${ }^{14}$ Nurullah Genc, N. Oyku Iyigun, dan Murat Yalcintas, "Mehmed Conqueror As A Case Study on Transformational Leadership," Eurasian Journal of Social Sciences 3(1) (2015): 26. 
the kings of Transylvania, Serbia, Venice, and Genoa launched the next Crusade, which they were defeated in the Varna war. There is no single force that can help their Christian brothers to prevent the Ottoman Turks from conquering the city of Constantinople, the capital of East Roman (Byzantium) in 1453 under the leadership of Sultan Muhammad Al-Fatih, which was a brilliant victory which became the way of Muslims in expansion and Islamization in Eastern European region. ${ }^{15}$

From Constantinople, the Ottoman Empire continued to move towards perfecting the liberation of the Balkans as far as the Danube and Aegean. Sultan Muhammad Al-Fatih, the ruler of Constantinople, pushed the defense of Serbia to the Danube in 1449. Half a century later, the Ottoman Turks controlled Greece, Bosnia, Herzegovina, and Albania. One of the factors of the Ottoman Turks in controlling these areas was because they were supported by the capacity of the Ottoman Turks in building political support from the former Byzantine slaves and Christian figures who were members of the Ottoman military and administrative duties. In addition, the tolerance that was carried out by the Ottoman Turks in protecting the Greek Orthodox Church was also an effort to get from the Balkans.

The implication of successfully conquering the territory of the Byzantine Empire actually led to a number of Muslim conversions in Anatolia, therefore this added a number of new territories to Islamic territory. Prior to the Muslim migration, Greeks, Armenians, Georgians, and Syrians in Anatolia were predominantly Christians. In the 15th century, more than $90 \%$ of the population was Muslim. Some of these changes were due in part to the migration of large numbers of Muslims, but most of these changes were due to the conversion of Christians to Muslims. ${ }^{16}$

Before being conquered by Muhammad Al-Fatih, Muslims tried to conquer Constantinople several times before the era of the Ottoman Turks. They were motivated by the Hadith of the prophet Muhammad from Abu Qubail saying:

"While we were at the house of Abdullah bin Amr bin Al-Ash, asked about the city of Constantinople and Rome, which of the two will be conquered first. Then Abdullah asked that a bound box be taken. Abdullah then said, "When we were recording around the prophet Muhammad, suddenly the prophet Muhammad was asked, which city will be conquered first, Constantinople or

${ }^{15}$ Ira M Lapidus, Sejarah Sosial Umat Islam, trans. oleh Ghufron A Mas'adi (Jakarta: Raja Grafindo Pustaka, 2000), 474.

${ }^{16}$ Lapidus, 547. 
Rome? Prophet Muhammad replied, first of all, the city Heraclius, he means the city of Constantinople". ${ }^{17}$

Motivated by the hadith of the prophet, to be able to conquer an area requires careful planning and strategy. So Sultan Muhammad Al-Fatih. build a fort on mainland Europe on the banks of the Bosporus Strait, opposite the fort that was built by Sultan Bayazid I. The implication is that he can take full control of the Bosphorus and can prevent reinforcements from arriving in Constantinople. ${ }^{18}$ Precisely in 1453 the Ottoman Turks took control of the city and ordered that the call to prayer be echoed at the Hagia Sophia Church as an announcement that the church was converted into a mosque. One thing that deserves to be mentioned here is that the Hagia Sophia Church was originally the headquarters of worldwide Orthodox Christianity, just as the Vatican is the world headquarters of Catholic Christianity. ${ }^{19}$

Also, Muhammad Al-Fatih ordered that the city be renamed Istanbul (Islam Bul) which means Islamic City, also used as the capital of the Ottoman state and continued to be its capital until the dissolution of the Ottoman Empire in 1924 by Mustafa Kemal Pasha, replaced with Turkey. Modern. Thus, the Byzantine Empire fell completely after more than 8 centuries. However, Sultan Muhammad Al-Fatih gave freedom to the conquered citizens of Constantinople to embrace their respective religions and wear all their religious symbols. Sultan Muhammad Al-Fatih also bought half of the churches in the city to be converted into mosques, while the other half were left as Christian churches so that they could practice their worship. ${ }^{20}$

\section{Turkey from a State of Caliphate to the Secular State}

As a result of the abolition of the caliphate, Mustafa Kemal Pasha declared Modern Turkey a secular state by abolishing Islam as the official religion in 1937. Previously Mustafa Kemal Pasha had abolished Islamic institutions in government including; The Syaik Al-Islam Bureau in 1924, abolition of the ministry of sharia, abolition of the Sharia Court, eliminating Arabic and Persian lessons in schools in 1928, eliminating religious education in schools in 1933. Mustafa Kemal Pasha died in 1938. ${ }^{21}$

During his tenure as the number one person in Turkey, Mustafa Kemal Pasha's various policies were Westernization in all aspects of life in Turkey,

${ }^{17}$ Tim Riset dan Studi Islam Mesir, Ensiklopedi Sejarah Islam; Imperium Muslim Mongol, Negara Usmani, Muslim Asia Tenggara, Muslim Afrika, 169.

${ }^{18}$ Douglas A. Howar, A History of the Ottoman Empire (Cambridge: Cambridge University Press, 2017), 113.

${ }^{19}$ Dedi Supriyadi, Sejarah Peradaban Islam (Bandung: Pustaka Setia, 2008), 267-68.

${ }^{20}$ Tim Riset dan Studi Islam Mesir, Ensiklopedi Sejarah Islam; Imperium Muslim Mongol, Negara Usmani, Muslim Asia Tenggara, Muslim Afrika, 173.

${ }^{21}$ Supriyadi, Sejarah Peradaban Islam, 267-68. 
especially in terms of civilization. The main theme of Westernization thinking is that Turkey should be part of the West in all behavior. For this reason, he implemented policies, one of which was the prohibition of wearing clothes that are considered religious clothing in public places and encouraging Turkish people to wear Western-style clothing. ${ }^{22}$

As a result of this, the Muslims in Turkey are carrying out the revival of Muslims which was spearheaded by Necmetin Erbakan, he built an Islamist movement in Turkey. One of his students was Recep Tayyip Erdogan with Abdullah Gul holding his teacher's successor relay. The victory of the AKP party (Adalet Ve Kalkinma Vartisi), namely the Justice and Development Party in the 2007 elections with the collaboration of Abdullah Gul and Recep Tayyip Erdogan succeeded in returning the lessons of the Koran and Hadith in public schools in Turkey and providing regulations on hijab freedom on campus- campus. ${ }^{23}$

Entering the 2002 election, the AKP formed by Erdogan was elected president of Turkey through the general election with $34.3 \%$ of the vote, the 2007 AKP election won 46.5\%, the 2011 election got 49.8\%, while in the 2015 election it got $49.5 \%$. This indicates the rise of Islam in Turkey since 1924 when Mustafa Kemal Pasha was seized by him. Erdogan's Islamist policies are still consistently carried out by Erdogan, including freeing the hijab in various sectors, supporting the struggle of the Palestinian people, supporting President Morsi who was overthrown, and most recently the most controversial policy changing the Hagia Sophia museum into the Hagia Sophia Mosque which mostly received negative responses. especially from Western countries. ${ }^{24}$

Erdogan's populist and Islamist leadership is a concern for Muslims in the world, especially those who want to establish a caliphate in this world, including in Indonesia. Why do they see Turkey as a role model because they believe and see historical facts that before Mustafa Kemal Pasha was replaced by a republican state (secular) by Mustafa Kemal Pasha, the Ottoman Turks became the unifier of the world's Muslims? One of its historical foundations is that the time of the prophet Muhammad to the Ottoman Turks was the Khilafah period. While the caliphate is a state theory that is in accordance with Islam. Meanwhile, the perfect application

${ }^{22}$ Imron Mustofa, "Turki Antara Sekularisme dan Aroma Islam; Studi atas Pemikiran Niyazi Berkes," El-Banat; Jurnal Pemikiran dan Pendidikan Islam 6(1) (2020): 56.

${ }^{23}$ Akhmad Rizqon Khamami, "Erdogan Versus Gulen: Perebutan Pengaruh antara Islam Politik Post-Islamis dengan Islam Kultural Apolitis," Al-Tahrir 16(2) (2016): 253.

${ }^{24}$ Ahmad Junaidi, "Kebijakan Politik Recep Tayip Erdogan dan Islamisasi Turki Kontemporer," In Right: Jurnal Agama dan Hak Asasi Manusia 6(1) (2016): 146.

Kodifikasia: Jurnal Penelitian Islam, Volume, 14 No. 2 Tahun 2020 
of Islam had been started from the time of the Prophet until 1918 before the colonialists controlled Muslim countries.

\section{Hagia Sophia and the Caliphate Issue in Indonesia}

The most intense khilafah movement in the world is carried by HizbutTahrir which was founded by Shaykh Taqiyuddin An-Nabhani in 1953 and officially registered with the Jordanian government, then dissolved by the Jordanian government. In Indonesia itself, the Hizbut Tahrir organization is signed by the name Hizbut Tahrir Indonesia (HTI). ${ }^{25}$ In the context of statehood, HTI adheres to the Islamic caliphate. This caliphate is a fixed price because it refers to the Islamic political system at the time of the prophets Muhammad and Khulafaurrasyidin. Through consistent struggle, HTI wants to change the state of the Republic of Indonesia into a caliphate. ${ }^{26}$ One way is to take advantage of advances in technology and information they pioneered Hizbut Tahrir in Indonesia (HTI) around the 1980s. Because the New Order regime allowed organizations to develop apart from the Communists, HTI founders with underground movements assisted by intelligence managed to infiltrate campuses which later co-opted campus mosques such as the Padjajaran University mosque in Bandung, the mosque of the Teacher Training and Education Institute (IKIP). ) Malang (now the State University of Malang), the mosque of the University of Jember, the Salman Mosque of the Bandung Institute of Technology (ITB), have even spread to outside the island of Java such as the Hassanudin Makassar University as well as through the Campus Da'wah Institute (LDK).

The impact is that those who study at universities, especially students who are not Islamic religious colleges, become an easy place to recruit cadres because their backgrounds are mostly not Islamic boarding school alumni. In this way the narratives propagated are scientific and exact, one of which is by taking the history of the past, especially when the Conquest of Constantinople by Sultan Muhammad Al-Fatih in 1453 with the present context that suggests that if Muslims bring back the caliphate like the Ottoman era, Muslims will experience the peak of glory again. In addition, they also made propaganda depicting that if the caliphate and the issue of

${ }^{25}$ Hizb ut-Tahrir is a political party with Islamic ideology. Hizb ut-Tahrir operates in the midst of society and together strive to make Islam the main issue, and guide them to re-establish the Khilafah system and enforce the law based on what Allah has revealed in this life. In addition, HTI is a political group, not a group that relies solely on spiritual aspects, not a scientific institution, not an educational institution (academic), not a social institution. Azman, "Gerakan dan Pemikiran Hizbut Tahrir Indonesia," Ad-daulah 7(1) (2018): 100.

${ }^{26}$ Syaiful Arif, "Pandangan dan Perjuangan Ideologis Hizbut Tahrir Indonesia (Hti) dalam Sistem Kenegaraan Indonesia," Aspirasi 7(1) (2016): 96. 
the Hagia Sophia mosque in Istanbul were exhaled, it would be a special attraction to recruit its members.

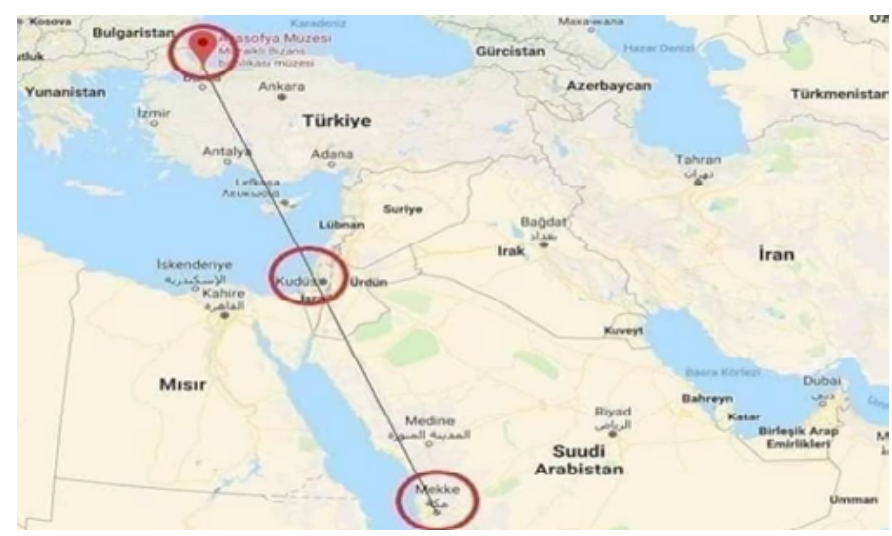

Figure 1.

The special prayer in the mosque of Hagia Sophia is facing two qibla at once, namely Al Haram Mosque and Aqsa Mosque (Source: Heriansyah, 2018).

In the context of a state in Indonesia, Hizbut Tahrir Indonesia (HTI) openly does not recognize Pancasila as the ideology of the Indonesian nation because according to them Pancasila is an infidel ideology. This is described by Ainur Rafiq, quoting an HTI leaflet entitled "Al-Banshasila Falsafah Kufr laa Tatafiq Ma'a Al-Islam." ${ }^{27}$ The implication is that contrary to Pancasila, the Indonesian government will revoke the HTI legal entity. ${ }^{28}$ thus making HTI fighters cornered, they become pressed, and limited space. Can no longer hide from intelligence. However, with the remaining energy, HTI continues to move. Their network remains solid. The activities of associations, recruitment, attacks on authorities, and efforts to approach military and police officers are certainly not as vulgar as before.

In terms of the state's great symbol, HTI itself believes that the Red and White flag is not an Islamic flag. Red and white flag of infidel country which is nationalism. The Red and White flag is not the flag of HTI as adhered to by them depicting the Tauhid flag. It is illegal for HTI activists to fly it. ${ }^{29}$

${ }^{27}$ Ainur Rafiq Al-Amin, Membongkar Proyek Khilafah ala Hizbut Tahrir Indonesia, Reform Review (Yogyakarta: LKiS, 2012), 62.

${ }^{28}$ The process of dissolving the Indonesian Hizbut Tahrir (HTI) Ormas through the Ministry of Law and Human Rights (Kemenkumham) by revoking the status of legal entities that are already owned, then the government issued a Government Regulation in Lieu of Law No. 2 of 2017 as a follow-up to the revocation of legal entities owned by Hizbut Tahrir Indonesia.

${ }^{29}$ Muhammad Herowandi, "Kontroversi Hizbut Tahrir Indonesia terhadap Pancasila" (Universitas Lampung, 2007), 29. 
The issue of Hagia Sophia, which has now become national and international news, becomes sensitive when discussing nationalism and nationality. It is a concern that the issue of the caliph, who had experienced its heyday, is no longer relevant to the context of the soul of its era. By looking at this phenomenon, we as citizens of Indonesia, especially Muslims, by studying history can see the trajectory of history according to its plot. The Ottoman Caliphate, which was once victorious when viewed in the context of the Islamic revival in Erdogan's era, deserves our support and appreciation because, in his government, Muslims began to gain rights and freedom from Turkey as a sovereign state.

If we see today with the abolition of legal entities and the ban on HTI organizations in Indonesia by President Joko Widodo, the radicalization of HTI sympathizers will look for various ways so that they get sympathy and support from the Indonesian people in various ways, one of which is the issue of Hagia Sophia which is the world's talk. They make historical narratives, facts, so that the issue of the caliphate that is contrary to Pancasila is following the teachings of the Muslim community and by utilizing the mass media that Pancasila is not a philosophy of life for Indonesian Muslims, on the contrary, that the ideology of the caliphate is the ideology of the Muslim community in the world that must remain guarded and championed by Muslims in the world, including in Indonesian..$^{30}$

Within the framework of Indonesian's, Pancasila as a philosophy of life for Indonesians should be maintained because the 5 precepts which are crucial points are one of the implementations of Islamic teachings where all Islamic elements are contained in it where the ulama are the spirit of the Indonesian nation in expelling the colonizers from the Indonesian state. Within this framework, Pancasila eventually became the basis for the political thought of the Indonesian people and mobilized the aspirations of all Indonesian people. ${ }^{31}$

\section{CONCLUSION}

Addressing the warm issue of religious identity changes occurring by Muslims especially with a long historical background as a country that has experienced success in the past ought to be seen from the beginning Hagia Sophia is the center of the World Orthodox Christian Church. Then became the most monumental mosque in Turkey Usmani and transformed

${ }^{30}$ Sudjito, Hendro Muhaimin, dan Agung Saras Sri Widodo, "Pancasila and Radicalism: Pancasila Enculturation Strategies as Radical Movement Preventions," Dinamika Hukum 17(1) (2018): 74.

${ }^{31}$ Syaiful Arif, "Kontradiksi Pandangan Hti atas Pancasila," Keamanan Nasional 2(1) (2016): 28. 
into the Hagia Sophia Museum by Mustafa Kemal Pasha and his status turned again into a mosque by the Turkish President Recep Tayyip Erdogan counted since 17 July 2020 being a conversation that seized humanity in this world.

If we look at the above, looking at the phenomenon with a historical approach is very reasonable and the highest leader of a country can do a free policy as long as it does not contradict the laws of its country and the majority of people support it. In this case, Erdogan as a populist figure and Islamist wanted the rights of the previous ruler where Sultan Muhammad AlFatih had made the church a mosque should be returned to the conquerors of Constantinople where there was a Hagia Sophia.

The implication, seeing the fact that Erdogan wanted to return the owner of the Hagia Sophia to the previous ruler. This became a real thing in Indonesia's hard-line Islamist groups utilizing the moment to support their underground movements carried by Hizbut Tahrir Indonesia. Wherewith a historical approach they strive to make propaganda that by carrying the concept of the caliphate of Muslims in Indonesia will experience the glory of the Ottoman Empire experienced. Nevertheless, as good and wise citizens it is very good that we are more cautious before acting to not be carried away. Where Indonesia with the ideology of Pancasila is an ideology that is consensus especially of Muslims to form and build Indonesia that until now we build together so that the nation of Indonesia becomes a strong nation and able to face the issues that are politicized in particular interests. 


\section{BIBLIOGRAPHY}

Al-Amin, Ainur Rafiq. Membongkar Proyek Khilafah ala Hizbut Tahrir Indonesia. Reform Review. Yogyakarta: LKiS, 2012.

Arif, Syaiful. "Kontradiksi Pandangan Hti atas Pancasila." Keamanan Nasional 2(1) (2016).

- "Pandangan dan Perjuangan Ideologis Hizbut Tahrir Indonesia (Hti) dalam Sistem Kenegaraan Indonesia.” Aspirasi 7(1) (2016).

Azman. "Gerakan dan Pemikiran Hizbut Tahrir Indonesia." Ad-daulah 7(1) (2018).

Dzulfaroh, Ahmad Naufal. "Beragam Respons Dunia atas Perubahan Status Hagia Sophia Menjadi Masjid.” kompas.com, 2020. https://www. kompas.com/tren/beragam-respons-dunia-atas-perubahan-statushagia-sophia-menjadi-masjid.

Genc, Nurullah, N. Oyku Iyigun, dan Murat Yalcintas. "Mehmed Conqueror As A Case Study on Transformational Leadership." Eurasian Journal of Social Sciences 3(1) (2015).

Herowandi, Muhammad. "Kontroversi Hizbut Tahrir Indonesia terhadap Pancasila." Universitas Lampung, 2007.

Hitti, Philip K. History of the Arabs; From the Earlist Times to the Present. New York: Palgrave Macmillan, 2000.

Howar, Douglas A. A History of the Ottoman Empire. Cambridge: Cambridge University Press, 2017.

Jaramaya, Rizky, dan Muhammad Hafil. "Yunani Kecam Turki Ubah Hagia Sophia Menjadi Masjid.” republika.co.id2, 2020. https://republika. co.id/berita/yunani-kecam-turki-ubah-hagia-sophia-menjadi-masjid. com.

Junaidi, Ahmad. "Kebijakan Politik Recep Tayip Erdogan dan Islamisasi Turki Kontemporer." In Right: Jurnal Agama dan Hak Asasi Manusia 6(1) (2016).

Khamami, Akhmad Rizqon. "Erdogan Versus Gulen: Perebutan Pengaruh antara Islam Politik Post-Islamis dengan Islam Kultural Apolitis." AlTahrir 16(2) (2016).

Kuntowijoyo. Metodologi Sejarah. 2 ed. Yogyakarta: Tiara Wacana, 2003. 
Lapidus, Ira M. Sejarah Sosial Umat Islam. Diterjemahkan oleh Ghufron A Mas'adi. Jakarta: Raja Grafindo Pustaka, 2000.

Mulyati, Sri. "Transformasi Budaya dari Khilafah Turki Utsmani Menuju Republik Turki Modern (1830-1950)." CMES (Center of Middle Eastern Studies) 7 (1) (2014).

Mustofa, Imron. "Turki Antara Sekularisme dan Aroma Islam; Studi atas Pemikiran Niyazi Berkes." El-Banat; Jurnal Pemikiran dan Pendidikan Islam 6(1) (2020).

Necipoglu, Gulru. Hagia Sophia from The Age of Justinian to The Present. Cambridge: Cambridge University Press, 199M.

Ott, Justin. The Decline and Fall of The Western Roman Empire. Iowa: Iowa State University, 2009.

Ratna, Nyoman Kutha. Metodologi Penelitian kajian Budaya dan Ilmu Sosial Humaniora pada umumnya. Yogyakarta: Ombak, 2020.

Ratnasari, Dewi. "Sulaiman Al-Qanuni: Sultan Terbesar Kerajaan Turki Utsmani." Thaqafiyyat 14(1) (2013).

Soekarba, Siti Rohmah. "Makna, Ruang dan Tempat, Pada Hagia Sophia, Istambul Turki." Middle East and Islamic Studies Journal 7(1) (2020).

Subarkah, Muhammad. "Hagia Sofia Menjadi Masjid: Bagaimana Sikap Indonesia?" republika.co.id, 2020. https://republika.co.id/berita/hagiasofia-menjadi-masjid-bagaimana-sikap-indonesia.

Sudjito, Hendro Muhaimin, dan Agung Saras Sri Widodo. "Pancasila and Radicalism: Pancasila Enculturation Strategies as Radical Movement Preventions." Dinamika Hukum 17(1) (2018).

Supriyadi, Dedi. Sejarah Peradaban Islam. Bandung: Pustaka Setia, 2008.

Tim Riset dan Studi Islam Mesir. Ensiklopedi Sejarah Islam; Imperium Muslim Mongol, Negara Usmani, Muslim Asia Tenggara, Muslim Afrika. Jakarta: Pustaka al-Kautsar, 2014.

Welle, Deutche. "Uni Eropa Kecam Turki atas Berubahnya Status Hagia Sophia.” republika.co.id, 2020. https://republika.co.id/berita/unieropa-kecam-turki-atas-berubahnya-status-hagia-sophia. 